ISSN: 2362-1303 (Paper) | eISSN: 2362-1311(Online)

JOURNAL OF ADVANCED ACADEMIC RESEARCH (JAAR) Jan 2016

\title{
Lived Experiences of People Living with Type II Diabetes: A qualitative study Saraswati Sharma ${ }^{1}$ \&Sarala Joshi ${ }^{2}$
}

${ }^{1}$ PhD Scholar Mewar University Rajasthan

${ }^{2}$ Assistant Dean Institute of Medicine, Co-coordinator of $\mathrm{PhD}$ program, nursing campus Maharajgunj Kathmandu

\section{Corresponding Author}

Saraswati Sharma

Nepalese Army Institute of Health Sciences, College of Nursing Kathmandu, sharmasaraswati505@yahoo.com, Mobile: 9841611122

\begin{abstract}
Introduction: Nepal is experiencing a double disease burden: Communicable diseases as well as rising incidence of non-communicable diseases. It is believed to be due to unhealthy life style and faulty food habit. Among the NCD Diabetes Mellitus (DM) is considered to be a major health problem.

Methods: This study has adapted Phenomenological approach in which the researcher has tried to explore the perceptions and beliefs of people living with type 2 diabetes. In this study two instruments were used; in-depth interview were taken in 21 respondents who are attending different hospitals of Kathmandu. The interview was guided by using open ended questions. All interviews were analyzed manually and qualitative content analysis was done to identify the codes, categorizes, sub categorizes concepts data and to find out the main theme.
\end{abstract}

Results: Most of the respondents believed that unhealthy diet(high carbohydrate, high fat, low rough phage food), sedentary life style, stressful life and consumption of the food with higher concentration of pesticides (eg: Metacid).

Conclusions: People perceived that unhealthy life style is the main cause of diabetes and to reduce the number awareness program should be initiated by the government mainly in the public places and should be kept in the school level curriculum also. 
ISSN: 2362-1303 (Paper) | eISSN: 2362-1311(Online)

Key words: Perceptions, Sedentary life, Type II Diabetes Mellitus, Unhealthy life style INTRODUCTION

The prevalence of diabetes is rising globally and it is estimated that over $60 \%$ of people with diabetes reside in Asia. Diabetes mellitus (DM) is a major emerging health problem that has reached epidemic proportion worldwide (Whiting, Guariguata, Weil, Shaw , 2010 ; Montgomery, Kamel,Saldana,Alavanja,Sandler, 2008). Nepal currently directs efforts towards curing diseases but pays little attention for preventive actions. The prevelance of diabetes in Nepal is increasing in the urban areas specially in kathmandu where unhealthy life style is gaining (Yadav, Sathian, Kalai,2012). Lack of awareness plays major risk factors for diabetes mellitus. Level of education is the most significant predictor of knowledge regarding risk factors, complications and the prevention of diabetes (Al Shafaee , Al-Shukaili , Rizvi , 2010).

"Diabetic patients are more responsible than the doctor and family in the care of diabetes" ( Vaidya , Shakya , Krettek ,2010). Diabetes disease management program appeared to be helpful in reduction of health care costs and hospital stay (Dulal, Karki ,2009). Most of the patients were aware of the disease known as diabetes but unaware about the type of diabetes they were suffering from (Al-Qazaz, et al 2011). The increasing diabetes trend can be prevented by providing information about maintaining and controlling weight, dietary modification and regular exercise by giving health education (Shrestha, Ghimirae, 2008). Participants' perceived diabetes as negative and destructive like blackness, end of romances, and a gradual death (Abdoli, Mardanian, Mirzaei ,2012).

Prevalence of obesity is associated to the increased sedentary lifestyle, consumption of fatty and processed food and using too much vehicle (Awah, Kengne, Fezeu, Mbanya,2008). There is risk of developing a number of serious health problems. Kidney disease (diabetic nephropathy) Nerve disease (diabetic neuropathy): Among the most commonly affected areas are the extremities diabetic foot ulcer, lead to pain, tingling, and 
ISSN: 2362-1303 (Paper) | eISSN: 2362-1311(Online)

loss of feeling and risk of amputation that may be more than 25 times greater than that of people without diabetes and eye disease (diabetic retinopathy) (Cade. ,2008). Some of the behaviors of participants considered beneficial for foot health could potentially increase the risk of ulceration because they thought that walking bare foot could be beneficial to the diabetic patient (Gale,Vedhara, Searle, Kemple, Campbell,2008). Perceptions and beliefs about the causes and complications of diabetes is viewed through Orem's self-care theory. (George, 2008).

The regular practice of yoga or exercise is an effective therapy in reducing blood glucose level (Ramachandran, Snehalatha, Shetty, Nanditha ,2012 ). People with types II diabetes mellitus both construct and draw upon causal accounts as a resource, and a means to counter their inability to balance medical outcomes and quality of life (Neil, Will , 2006).

\section{METHODS}

The study was conducted between June-September 2015 in three hospitals of Kathmandu valley, Bir hospital, Patan hospital and Jorpati community hospital after acquiring ethical permission from Nepal Health Research council and then from the respective hospitals. Indepth interview were taken from 21 respondents, who were diabetic clients by using pretested questionnaire. This study has adapted Phenomenological approach in which the researcher has tried to explore the perceptions and beliefs of people living with type 2 diabetes. Individual interview was taken with policy level authority who works in the health sector. For efficient data collection and proper interview, the researcher has managed a record keeper and digital tape recorder. Pretested open ended questions were used which were in Nepali language and all the respondents understood Nepali language properly. All the qualitative data were manually analyzed. All the information were transcribed by researcher herself. Qualitative content analysis was done by extracting meaningful units, their condensation and abstraction.

Example of qualitative analysis with meaningful units their condensation and their abstraction shown in table: 1 
ISSN: 2362-1303 (Paper) | eISSN: 2362-1311(Online)

JOURNAL OF ADVANCED ACADEMIC RESEARCH (JAAR)

\begin{tabular}{|c|c|c|c|c|c|c|}
\hline $\begin{array}{l}\text { Respondent } \\
\mathrm{s}\end{array}$ & $\begin{array}{l}\text { Meaningful } \\
\text { unit }\end{array}$ & $\begin{array}{l}\text { Condensed } \\
\text { meaningful } \\
\text { unit }\end{array}$ & Codes & $\begin{array}{l}\text { Sub } \\
\text { subcategorie } \\
\text { S }\end{array}$ & Subtheme & Theme \\
\hline R 5 & $\begin{array}{l}\text { Diabetes } \\
\text { means } \\
\text { related to } \\
\text { unhealthy } \\
\text { food intake } \\
\text { that is too } \\
\text { much oily } \\
\text { food, high } \\
\text { sugar intake, } \\
\text { carbohydrate } \\
\text {, and low } \\
\text { fruits and } \\
\text { vegetables. }\end{array}$ & $\begin{array}{l}\text { Unhealthy } \\
\text { food with } \\
\text { high } \\
\text { carbohydrate } \\
\text {, sugar, fatty } \\
\text { food and low } \\
\text { vegetable } \\
\text { cause } \\
\text { diabetes. }\end{array}$ & $\begin{array}{l}\text { High } \\
\text { carbohydrate } \\
\text {, fat and } \\
\text { sugar } \\
\text { Contained } \\
\text { food }\end{array}$ & $\begin{array}{l}\text { High } \\
\text { carbohydrate } \\
\text {, sugar and } \\
\text { fat }\end{array}$ & $\begin{array}{l}\text { Unhealth } \\
\text { y food }\end{array}$ & \multirow{3}{*}{$\begin{array}{l}\text { Diabetes } \\
\text { is a } \\
\text { disease } \\
\text { of } \\
\text { unhealthy } \\
\text { food } \\
\text { intake } \\
\text { Sedentar } \\
\text { y life } \\
\text { style and } \\
\text { incurable } \\
\text { disease. }\end{array}$} \\
\hline R10 & $\begin{array}{l}\text { Diabetes } \\
\text { means } \\
\text { disease } \\
\text { caused due } \\
\text { to increase } \\
\text { weight. } \\
\text { Disease that } \\
\text { is caused by } \\
\text { not doing } \\
\text { exercise. }\end{array}$ & $\begin{array}{l}\text { Due to } \\
\text { increase } \\
\text { weight and } \\
\text { not doing } \\
\text { exercise }\end{array}$ & $\begin{array}{l}\text { weight } \\
\text { exercise }\end{array}$ & $\begin{array}{l}\text { Unhealthy } \\
\text { life style }\end{array}$ & $\begin{array}{l}\text { Sedentary } \\
\text { life }\end{array}$ & \\
\hline R19 & $\begin{array}{l}\text { Diabetes } \\
\text { means a } \\
\text { disease that a } \\
\text { people } \\
\text { should take } \\
\text { medicine } \\
\text { lifelong have } \\
\text { to suffer } \\
\text { lifelong. }\end{array}$ & $\begin{array}{l}\text { Lifelongs } \\
\text { medicine } \\
\text { Lifelong } \\
\text { suffer }\end{array}$ & $\begin{array}{l}\text { Lifelong } \\
\text { medicine } \\
\text { incurable }\end{array}$ & $\begin{array}{l}\text { Medicine } \\
\text { Incurable }\end{array}$ & $\begin{array}{l}\text { Insulin } \\
\text { resistant } \\
\text { low } \\
\text { secretion } \\
\text { of insulin }\end{array}$ & \\
\hline
\end{tabular}

Source: (Graneheim \& Lundman,2004)

\section{RESULT}

The researcher has interviewed 21 diabetes client, the average age of participants were 
ISSN: 2362-1303 (Paper) | eISSN: 2362-1311(Online)

$56.4 \pm 6.16$ years (Male: $54.76 \pm 6.88$ years and female59.75 \pm 2.91 ) and the average duration of diabetes was $8 \pm 2.49$ years.

According to developed questionnaire, the themes were analyzed.

In your opinion what is the meaning of diabetes?

Almost all respondents who were suffering from diabetes viewed that it is a sugar disease (chini rog). Disease that is caused by high intake of carbohydrate, oily food, disease of obese people and rich people and it is as illustrated by the quote below:

Sugar disease. "Chinirog. I think" Disease seen in people who eat lots of food that is rich in carbohydrate, potatoes and oily food. ....this is a disease of lazy people who do not do physical exercise....( IDI,R1)

\section{Risk factors of diabetes:}

\section{Food habits}

All respondent said that it is because of unhealthy food habit that is high in carbohydrate, fat and sugar intake, due to consumption of lots of fatty meal as illustrated by the quote below:

I think diabetes is due to unhealthy food, eating too much fatty and carbohydrate contained food.IDF,21).

\section{Sedentary life}

Most of the respondent said people are becoming lazy; they don't want to walk short distance as illustrated by the quote below:

People want to spend easy and comfortable life without doing any exercise. (IDF,12).

Stressful life most of the respondent said that nowadays people life is becoming very much stressful so it may cause diabetes. One of the respondents said:

I think .....Diabetes and stressful life is connected (IDF,20)

Diabetes complication

The entire respondent heard about diabetic complication. One of the respondents said that:

I think the most common problems are kidney problem and foot ulcer, and I'm suffering from this problem. It is taking too long to be healed. (IDF, R13).

Prevention from complication

Vol. 3. No. I

www.phdcentre.edu.np 
ISSN: 2362-1303 (Paper) | eISSN: 2362-1311(Online)

Most of the respondents said that if we are serious about diet control, exercise, regular medical checkup and regular intake of medicine then we can prevent further complications. One of the respondents saying as illustrated by the quote below:

"I believe that even after suffering from diabetes, by preventing further complications we can live a healthy life for that we have to do morning walk regularly for one hour and control the diet. (IDF,5)"

Mitigation of emerging problem in our context

Almost all respondent said by conducting awareness programs involving health personnel and schools the disease can be controlled. Awareness should be spread specially about the risk factor of diabetes.

One of the respondent said that "I believe that no one can do anything but the person him/herself should be conscious about health" (IDF,R 7).

\section{Role of government to reduce the number of diabetic patients}

Most of the respondents said that first of all government should start with the awareness programs about the risk factors and ways of preventing them in schools, public places, from where lots of people can be well informed.

I think government can do a lot to prevent diabetes like awaring people regarding the causes of diabetes, incorporate the risk factors of diabetes in the school level curriculum (IDF,1).

\section{DISCUSSION}

This study was done to explore the perceptions and beliefs about diabetes regarding what it means to him/her, situation in local area, Nepal and in the world, risk factor complication and its prevention, how to mitigate the emerging problem and the role of government to prevent diabetes. Most of the respondents understood diabetes as sugar disease (Chinirog) that is connected with unhealthy lifestyle, lifelong disease, and killer disease. Similar finding described in other study (Yadav ,Sathian, Kalai, 2012).

Majority of respondents perceived that prevalence of diabetes is increasing and becoming common health problem in their local area and in Nepal. Similar finding suggests the same thing (Abdoli , Mardanian, Mirzaei ,2012). Most of the respondents believe that risk factors 
ISSN: 2362-1303 (Paper) | eISSN: 2362-1311(Online)

of diabetes is directly related to consuming lots of sugar, oily food and food with high concerntration of carbohydrate, sedentary life style, lack of physical work and increased use of vechicals. People become obese as a result of unhealthy life style which leads to diabetes the result corresponds with elsewhere (Dulal, Karki ,2009). Also most of the respodents blame farmers for using pesticides and chemicals without any knowledge about how much they have to use. The finding correlates with other studies (Cade, 2008).

Almost all the respondents have heard about diabetic complications and mentioned about non healing food ulcer, heart problem, nerve problem. The result matched with the other similar studies (Thabit, 2012).Result did not match with the study in which the result shows that most participants were unsure of what a foot ulcer is and difficulties associated with ulcer healing (Maskey,et.al2012; Sharma,Gupta , 2014). To prevent the complications, one should maintain healthy life style like consuming healthy food, regular exercise, regular blood check up and taking medicines regularly. Similar study corresponds with this study (Shrestrha, Ghimirae, 2012).

Most of the respondents believe that to mitigate the emerging problem one should attend yoga classes so that one can be released from tension. Similar study supports the present study (Shigidi, Abdelgafar, Taha ,2013; Frank ,2011).

People perceive that government can do a lot of things to control diabetes in Nepal and they as the number is increasing, risk factors should be emphasized and incorporated in school level curriculum, government should provide free medicine and free laboratory facility to the people who cannot afford to treat the disease.

\section{CONCLUSION}

The study concludes that the view of diabetic clients and policy level authority of heath sector is almost similar. All of them explored that diabetes is wide spreading in Nepal and main cause of diabetes is unhealthy life style. Also they added that even after suffering from diabetes people can lead a healthy life and prevent further complications. For this, regularity in exercise, health check-up, medicine intake and intake of healthy food should be maintained. 
ISSN: 2362-1303 (Paper) | eISSN: 2362-1311(Online)

\section{REFERENCES}

Abdoli, S., Mardanian, L.\& Mirzaei, M. (2012). How public perceive diabetes: A qualitative study.Iran J Nurs MidwiferyRes, 17 (5), 370-4.

Al-Qazaz, H.K., et al. (2011).Perception and knowledge of patients with type 2 diabetes in Malaysia about their disease and medication: a qualitative study,7 (2), 180-91.

Awah, P.K., Kengne, A.P., Fezeu,L.L.\& Mbanya, J. (2008). Perceived risk factors of cardiovascular diseases and diabetes in Cameroon. Health Education Research, 23 (4), 612-20.

Cade, W. (2008). Diabetes-Related Microvascular and Macrovascular Diseases in the Physical Therapy Setting. Journal of the American physical Theraphy Association, 88 (11), 1322-35.

Dulal, R.K.\& Karki, S.( 2009) Disease management programme for diabetes mellitus in Nepal. JNMA J Nepal Med Assoc,48 (176) ,281-6.

Frank ,B.H. (2011). Globalization of Diabetes: The role of diet, lifestyle, and genes. Diabetes care .American Diabetes Association, 24 (6),1249-1257.

Frost, J., Garside, R., Cooper, C.\& Britten ,N. (2014).A qualitative synthesis of diabetesselfmanagement for long termmedical outcomes and quality of life in the UK. $B M C, 14(348)$.

Gale, L., Vedhara, K., Searle, A., Kemple, T.\& Campbell, R. M. (2008).'Patients' perspectives on foot complications in type 2 diabetes: a qualitative study'. British Journal of General Practice,58(553), 555 - 63.

George, J .B. (2011). Nursing Theories The Basis For professional Nursing Practice (6th ed.). New Delhi ,India Binding House.

Graneheim, U.H.\&Lundman,R. (2004). Qualitative Content Analysis in Nursing Research: Concepts, Procedure and Measures to Achieve.Trustworthiness.Nurse Education Today, 24, 105-112.

Mangaiarkkarasi, A., Nitya, S., Mehar, R. A,\& Ramaswamy, S. A. (2012). Study to Assess the knowledge, attitude and practice about diabetes among Diabetic Patients in 
ISSN: 2362-1303 (Paper) | eISSN: 2362-1311(Online)

Pondicherry. Research Journal of Pharmaceutical, Biological and Chemical Sciences.3 (4), 1185-92.

Maskey, R., Shakya, D., Sharma,S., Karki, P.\& Lavaju, P.( 2012).Diabetes mellitus related complications in out- patient clinic of tertiary care hospital. Journal of College of Medical Sciences, 7 (2), 9-16.

Montgomery, M.P., Kamel. F., Saldana, T. M., Alavanja, M. C. R.\& Sandler, D. P. (2008) . Incident Diabetes and Pesticide Exposure among Licensed Agricultural Health. $\underline{A m ~ J}$ Epidemiol, 167(10),1235-46. doi: 10.1093/aje/kwn028.

Neil, J. S.\& Will, G.H. (2006). Effects od different modes of exercise training on glucose control and risk factors for compliocations in Type 2 Diabetic patients.American Diabetes Association, 29 (11), 2518-27.

Pokharel,D.R.,Gautam,N.,Archana,J.,Nagamma,T.,Kumar,R.\&Sapkota,R.M.(2011).Frequen cy of Type 2 Diabetes mellitus and Impaired Glycemia in a Teaching Hospital of South-Western Nepal. Asian Journal Of Medical Sciences,202-206.

Ramachandran, A., Snehalatha, C., Shetty, A.S., Nanditha, A. (2012).Trends in prevalence of diabetes in Asian countries. World Journal of Diabetes,3(6),110-17.

Sharma, N.,\& Gupta, N. (2014). Effect of yoga on glycemic profile in diabetics. International Journal of Medical Science and Public HealthInt J Med Sci Public Health, 3(9), 1135-40doi: 10.5455/ijmsph.2014.020720141

Shigidi, M., Abdelgafar, H.,\&Taha, E.S. (2013). Awareness regarding diabetes control and diabetic nephropathy among Sudanese addults admitted with diabetic foot:a cross sectional study. The Pan African Medical Journal,16 (157), 3452-62.

Shrestrha,P.,\& Ghimirae,L. (2012). A review About the Effect of Life Style modification on on diabetes and Quality of life. Global Journal of Health Science,4(6),185-90. doi: 10.5539/gjhs.v4n6p185.

Thabit, M. F.(2012).Awareness regarding diabetes mellitus and it's complications in Type 2 Diabetic Patients. Al Kindy College Medical Journal.9 (2), 25-28.

Vaidya, A., Shakya, S.\& Krettek, A. (2010) Obesity Prevalence in Nepal: Public Health Challenges in a Low-Income Nation during an Alarming Worldwide 
ISSN: 2362-1303 (Paper) | eISSN: 2362-1311(Online)

JOURNAL OF ADVANCED ACADEMIC RESEARCH (JAAR) Jan 2016

Trend.International Journal of Environmental Research and Public Health, 7 (6), 2726-44.

Whiting, D.R., Guariguata, L., Weil, C.\& Shaw, J.( 2010). IDF diabetes atlas: global estimates of the prevalence of diabetes for 2011 and 2030. Diabetes Res Clin Pract, 94 (3), 311-21.

Yadav, N .K., Sathia, B., \& Kalai, R.S. (2012).Assessment of Diabetes Mellitus in India and Nepal.Webmed Central BIOCHEMISTRY 20123(6):doi: 10.9754/journal.wmc. 